\title{
CLINICAL COURSE: A CONCEPT ANALYSIS
}

\section{Eben Arries}

D Cur

Lecturer, Department of Nursing Science, Rand Afrikaans University

Corresponding author: ea@edcur.rau.ac.za

\section{Diana du Plessis}

D Cur

Senior lecturer, Department of Nursing Science, Rand Afrikaans University

Key concepts: clinical; clinical supervision; course; curriculum; education; concept analysis

\section{SUMMARY}

Concepts are the most basic linguistic constructs with which individuals can get a grasp on their reality. Concepts assist persons to organise their experiences. Furthermore, concepts facilitate communication and enable the cognitive recall of phenomena that may not immediately be present (Rodgers, 1989:330). However, if the meaning of a concept is vague and ambiguous, communication can be impaired. The concept "clinical course" is frequently referred to within nursing education discourse. It appears from the observation of nurse educators that there is much uncertainty about the meaning of this concept. The uncertainty is about which courses can be regarded as clinical courses. The purpose of this article is to describe the meaning of the concept clinical course. A philosophical analytical research design (Burns \& Grove, 1993:592) was followed in order to reach this purpose. The analysis of the concept "clinical course" was based on Rodgers' (1989) method of concept analysis. The aim of concept analysis was twofold - on the one hand it was done to clarify the meaning of the concept "clinical course" and on the other to formulate a definition of this concept. Based on the concept analysis, the following definition of the concept "clinical course" in nursing was formulated: A clinical course in nursing refers to a planned, contextual, needs-driven, interactive education and training programme, under the supervision of a clinical educator/facilitator, that leads to a clinical nursing qualification. The aim of a clinical course is to develop clinical competencies and to achieve set clinical outcomes by means of experiential learning. This confers on the holder of such clinical qualification the right to register such qualification as an additional qualification in terms of section 22 of the Nursing Act.

\section{OPSOMMING}

Konsepte is die mees basiese linguistiese konstrukte waarmee individue ' $n$ greep op hulle werklikheid bekom. Konsepte help persone om hulle ervarings te organiseer. Verder fasiliteer dit kommunikasie en stel dit persone in staat om bepaalde verskynsels wat nie onmiddelik teenwoordig is nie, op 'n kognitiewe wyse te herroep (Rodgers, 1989:330). Indien die betekenis van 'n konsep egter vaag en dubbelsinnig is, kan kommunikasie belemmer word. Die konsep "kliniese kursus" is 'n konsep waarna daar gereeld binne die diskoers oor verpleegopvoeding verwys word. Dit blyk egter vanuit die waarneming van verpleegopvoeders dat daar onsekerheid bestaan rondom die betekenis van die konsep, spesifiek oor watter kursusse in verpleegkunde as kliniese kursusse beskou kan word. Die doel van hierdie artikel is om die betekenis van die konsep "kliniese kursus" te beskryf. "n Filosofies-analitiese navorsingsontwerp (Burns \& Grove, 1993:592) is gevolg ten einde hierdie doelwit te bereik. Die konsep "kliniese kursus" is aan die hand van Rodgers (1989) se metode van konsepanalise ontleed. Die doelwit van die konsepanalise was tweeledig van aard - enersyds om die betekenis van konsep kliniese kursus te verduidelik en andersyds om ' $n$ definisie daarvan te formuleer. Vanuit die konsepanalise is die volgende definisie van die konsep "kliniese kursus" geformuleer: ' $n$ Kliniese kursus in verpleegkunde dui op 'n beplande, kontekstuele, behoefte-gedrewe interaktiewe onderrig- en opleidingsprogram onder die toesig van ' $n$ kliniese opvoeder/fasiliteerder wat tot ' $n$ kliniese 
verpleegkwalifikasie lei. Die doelwit van ' $n$ kliniese kursus is om kliniese bevoegdhede te ontwikkel en om gestelde uitkomstes deur middel van ervaringsleer te bereik wat aan 'n persoon die reg gee om sodanige kliniese kursus as ' $n$ addisionele kwalifikasie ingevolge artikel 22 van die Wet op Verpleging te registreer.

\section{INTRODUCTION}

Futurists have been warning for decades that nursing in the $21^{\text {st }}$ century would look very different from $20^{\text {th }}$ century nursing. We are beginning to believe them. In a provocative statement published in the summer of 2001, Tim Porter-O'Grady (2001:183) declared that "nursing practice in the current configurations and forms is dying, as the demands of the health system are changing both substance and service. The role of the clinical executive is to end the practice of nursing, as we have known it. Time-based nursing care with the activities of bathing, treating, changing, feeding, intervening, drugging and discharging are quickly becoming historic references to an age of practice that no longer exists."

As nurse educators we continue to struggle with our time-honoured approaches to clinical teaching. The "outcry" from clinical practice for competent clinical nursing practitioners and the way in which clinical courses are structured simply causes the gap between theory and practice to widen further. Outcomes-based education has become the buzzword in the discourse on higher education in South Africa. Outcomes-based education has it roots firmly embedded in earlier work on educational objectives and competency-based education (Van der Horst \& McDonald, 1997:8).

Competency-based education focuses on the achievement of specific competencies, whereas outcomesbased education focuses on three aspects: knowledge, skills and attitudes. In nursing, clinical teaching was adopted as the vehicle to achieve the educational outcome of nursing. According to Mellish, Brink and Paton (1998:207), clinical teaching is the means by which student nurses learn to apply the theory of nursing so that an integration of theoretical knowledge and practical skills (attitudes and values) in the clinical situation becomes the art and science of nursing. Therefore, clinical teaching can be regarded as a way of bridging the theory-practice gap in nursing, aiming at producing a competent registered nurse capable of giving expert nursing care that is based on sound knowledge, practical skills and attitudes. Mellish et al. (1998:208) are of the opinion that in order to achieve this aforementioned aim, clinical teaching must be based on theory and applied in practice. It must include teaching such skills as leadership and administration, teaching, organising and controlling of staff, the determination of work methods and procedures, the economical use of equipment and materials, the drawing up of appropriate nursing care plans, supervision, and control of the unit as a whole.

Revolutionising clinical nursing education is no longer an option, it is an obligation. Basic nursing care of the $20^{\text {th }}$ century is simply not relevant in the $21^{\text {st }}$ century. Technology, the accessibility of information and of health care, the emerging impact of genomics and the move toward primary health care services, or what Tanner (2002:51) calls "early engagement health services", should alter dramatically what we teach. Moreover, new understandings of how human beings learn from their experiences also shape our processes of clinical instruction. Therefore, in the light of these challenges, nurse educators must ask themselves what the new model of clinical education and clinical courses will look like. In order to deal with something, however, one has to understand what that something is, which brings us back to the concept of clinical courses.

In recent years, considerable attention has been directed towards the development and clarification of the knowledge base of nursing. A concern with concepts and the resolution of conceptual problems has increasingly emerged as a component of this process of intellectual advancement. Such an emphasis on concepts is appropriate, as concepts play an important role in the development of knowledge and even in the conduct of everyday existence. Concepts are the most basic linguistic constructions in the process of knowledge development with which humans can get a grasp on reality. Rodgers (1989:330) is of the opinion that concepts promote the organisation of experience, facilitate communication amongst individuals and enable the cognitive recall of phenomena 
that may not be immediately present.

When the definition or attributes of a concept are not clear, the ability of the concept to assist in the fundamental tasks is greatly impaired. In such situations, according to Rodgers (1989:330), it is difficult at best to identify an instance of a particular concept and to distinguish such an occurrence from one that is not an example of the concept. Communication is consequently impaired as questions regarding vague or ambiguous concepts are met with confused responses that are dependent upon individual and often ad hoc interpretations.

Nursing practice requires integration of thinking, feeling and doing, focusing on performance and judgement in handling many concepts and many levels of problems. Nurse practitioners are expected to have higher-order communication skills, competent technical skills and the ability to make decisions in the demanding and complex context of practical situations (Edmond, 2001:251; Grealish, 2000:231). Nursing is a highly complex and challenging profession that exists within a rapidly changing health care environment. It is thus imperative that nurses be proficient in the current knowledge and competencies necessary for providing safe and effective care (Bowles, 2000:373).

The importance of quality in health care in general, but nursing care in particular, has become more marked over the past five years. Measures to improve the quality of nursing care within the context of the reduced availability of nursing staff question the accepted boundaries of professional roles (Richardson \& Maynard, 1995). In particular, opportunities have risen for nurses to extend their practice (Read, 1995 in Chalmers, Swallow \& Miller, 2001:597). In doing so, the knowledge, skills, attitudes and values required of the nurse practitioner necessitate a re-look at the programmes that prepare nurses to perform these functions. This, therefore, brings us back to the issue of nursing education and training.

Nursing education and training in South Africa is currently undergoing change. In terms of both undergraduate and post-graduate nursing education programs, this involves, in part, an attempt to ensure that nurses are clinically competent and are deliver- ing high-quality nursing care. Tension between nursing education and training is a feature of the discourse on higher education.

Clinical teaching and learning is an integral part of nursing education, yet clinical education has been problematic. Clinical education is a vital component in the curricula of nursing as it provides student nurses with opportunities to develop competencies in nursing practice (Chan, 2002:69). Roche (2002:365) is of the opinion that in the practice discipline of nursing clinical learning experiences are necessary to acquire clinical decision-making skills. In achieving such skills, the clinical curriculum or course is central to such a clinical nursing education programme.

\section{PROBLEM STATEMENT}

The concept clinical course is a concept that is frequently referred to within the discourse in nursing education. Yet, this concept does not seem to be welldefined, especially given the changes that occur in the higher education system in South Africa in general, but in nursing in particular. These widespread changes are concerned with the South African education system and the implementation of a relevant and accountable curriculum at tertiary educational level, where nursing education fits in. With the movement of nursing to higher education in the country, many changes in the education arena occurs. One such change relates to the regulation of distant education programmes (South African Government, 1997). The uncertainty about the offering of clinical nursing programmes at tertiary education institutions on a distant education level accompanies such changes. This issue has become a point of major debate amongst nurse educators within such tertiary education institutions. Part of the debate deals with courses that should be regarded as clinical courses.

At an annual general meeting of the Forum of University Departments in South Africa (FUNDISA, 2001), nurse educators from 18 universities expressed their concern about the teaching of clinical courses through distant education. This triggered much debate amongst these nurse educators. In looking at the debate more closely, however, it seems that the reason for the debate has to do with an uncertainty about the meaning of the concept clinical course. 
The meaning of the concept clinical course is rather ambiguous and vague, hindering communication amongst nurse educators. This creates uncertainty about the meaning of the concept, regardless of the definition given by the South African Nursing Council (SANC, 1993). The SANC defines a clinical course as "... a program of education and training approved by Council, presented by an approved nursing school referred to in section 3 , which leads to a clinical nursing qualification that confers on the holder thereof the right to register such qualification as an additional qualification in terms of section 22 of the [Nursing] Act (Regulation 212 of 19 February 1993:1)."

In focusing on the SANC definition of a clinical course, it is not surprising why such confusion exists. It is not clear from the definition what the criteria would be against which such "... a program of education and training..." would be evaluated for approval. In addition, although the definition refers to "a clinical nursing qualification", it is unclear what processes and outcomes are involved that would lead to such a qualification. Furthermore, the definition is rather ambiguous, as according to its wording, all programmes in nursing are regarded as clinical courses, which is not necessarily true. Lastly, within the dynamic context in which nursing education occurs today, one can question the relevance and applicability of such a definition in assisting nurse educators in achieving the social and educational goals of the country. Clarity on the meaning of the concept clinical course should be sought. The following question therefore arose:

What is the meaning of the concept clinical course?

\section{PURPOSE OF THE ARTICLE}

The purpose of this article is to describe the meaning of the concept clinical course.

\section{RESEARCH DESIGN AND METHOD}

Within a philosophical analytical research design (Burns \& Grove, 1993:592), the primary purpose of philosophical analysis is to examine meaning and to develop theories of meaning. This is usually accomplished through concept analysis. Concept analysis is defined as a formal linguistic exercise to determine those defining essential attributes of a concept (Walker \& Avant,
1995:37).

\section{Method of concept analysis and develop- ment}

Rodgers' (1989) method of concept analysis was chosen for this analysis. The steps in Rodgers' (1989) process of concept analysis are reflected in Table 1.

The aim of concept analysis is to clarify the meaning of the concept clinical course and to formulate a definition in order to assist nurse educators' understanding thereof. Rodgers (1989) has developed an evolutionary approach to concept analysis within which she argues that concepts are abstractions that may be expressed in a discursive and non-discursive way. She further argues that "... through socialization and repeated public interaction, a concept becomes associated with a particular set of attributes that constitute the definition of a concept." According to Rodgers (1989:332-334) concept development has three phases, viz. significance, use and application. This approach appears to be useful when analysing the concept clinical course.

\section{The significance of the concept}

According to Rodgers (1989:332), the significance of an existing concept plays an important role in the concept's continuing development. Rodgers (1989:332) points out that "concepts acquire meaning through serving the relevant human purpose in actual practical cases". This "relevant human purpose" is related to the concept's ability to assist in the resolution of problems and its ability to characterise phenomena adequately, thus furthering efforts towards achievement of intellectual ideals. A concept that is considered significant will be used often, ultimately facilitating the development of productive innovations and variations.

The clarification of the concept clinical course in nursing education will probably add to the uncertainty that stems from the different ways in which it is interpreted in nursing. This might assist nurse educators to finally clarify what courses in nursing should or must be regarded as clinical courses.

The significance of the concept, according to Rodgers (1989:332), has considerable impact on its frequency 
Table 1: Method of concept analysis (Rodgers, 1989)

- $\quad$ Identify and name the concept.

- Identify surrogate terms and relevant uses of the concept.

- Identify and select an appropriate realm (sample) for data collection.

- Identify the attributes of the concept.

- Identify the references, antecedents and consequences of the concept, if possible.

- Identify concepts that are related to the concept of interest.

- Identify a model case of the concept.

and the extent of its use. The use of a concept, in this regard, is the common manner in which the concept is currently employed, the situations appropriate to its application and whether or not the use occurs through language or some other form of presentation. Usage carries with it the attributes of the concept that aids in the organisation of human experience (Rodgers, 1989:333).

In the literature study, surrogate terms and relevant uses of the concepts clinical (Table 2) and course (Table 3), as it occurs in nursing and educational literature, were identified.

Not only literature pertaining to nursing was studied, but also literature on education and of other disciplines. The purpose was to identify the use of the concept clinical course. Surrogate terms like clinical education, clinical curriculum and clinical instruction (Longstreet \& Shane, 1993:53; Taba, 1962; Van Hoozer, Bratton, Ostmoe, Weinholtz, Craft, Gjerde \& Albanese, 1987:174-175) were searched for, as these terms are frequently used to refer to a clinical course.

\section{Way in which a concept is used}

Rodgers (1989:333) states that when a concept becomes associated with a particular use and this understanding is passed on through social interaction and education, there are continuing efforts to apply the concept in future encounters. Application thus results in the identification of the scope or range over which the concept is effective. Through the process of application, an existing concept may be continually refined or conceptual variations and innovations may be introduced. Consequently, the concept may be enhanced in its explanatory or descriptive powers and may thereby offer a greater contribution to the attainment of intellectual ideals.

Over time the use of the concept clinical course has become vague or ambiguous. The nursing literature further indicates that there are concepts that appear to be in competition or conflict with the concept clinical course, for example, clinical programme, teaching, education (Mellish et al. 1998:207-208), or experiential learning programme (Coleman in Keeton, 1976:49$61)$, to name but a few.

\section{Application of the concept}

To identify the use and the application of the concept clinical course, as it is commonly referred to during social interaction, the nursing science departments of 18 South African universities were approached. Contact details were obtained from the newsletter of the Forum for University Departments in South Africa (FUNDISA, 1999), as the problem with the meaning of the concept clinical course originated from the uncertainty among the members of the departments who make up FUNDISA. Their opinions about the use and application of the concept as it appears during social interaction were therefore explored. This exploration was undertaken during the period September 2001 and November 2001. After the initial identification of the categories of characteristics of the concept clinical course, a preliminary definition based on these categories was formulated. This definition, together with the categories on which such formulation was based, was sent via e-mail to fourteen of the $18 \mathrm{mem}$ ber nursing departments of FUNDISA. 
Table 2: Surrogate terms and analysis of the concept clinical

\begin{tabular}{|c|c|c|}
\hline COLUMN 1 & COLUMN 2 & COLUMN 3 \\
\hline $\begin{array}{l}\text { 1. The American Heritage Dictionary defines clinical [course] as "...those } \\
\text { activities that students engage in while providing nursing care to or for } \\
\text { clients" (Van Hoozer et al. 1987) }\end{array}$ & $\begin{array}{l}\text { Activities that learners engage in } \\
\text { while providing nursing care to or for } \\
\text { clients }\end{array}$ & $\begin{array}{l}\text { Contextual programme } \\
(16,21,26,27,36,94)\end{array}$ \\
\hline $\begin{array}{l}\text { 2. [Clinical course applies to] "....any context where patient or client groups } \\
\text { are provided with services relating to health and should not be restricted to } \\
\text { its literal meaning of 'bedside'... clinical area in a social setting" (Quinn, } \\
\text { 1980) }\end{array}$ & $\begin{array}{l}\text { "context where patient or client } \\
\text { groups are provided with services } \\
\text { relating to health" } \\
\text { "social setting" }\end{array}$ & $\begin{array}{l}\text { Needs-driven programme }(17,2: \\
32,37,119)\end{array}$ \\
\hline $\begin{array}{l}\text { 3. [Clinical ] "...based on, or relating to, direct observation and treatment of } \\
\text { the patient, as distinct from theoretical or experimental work" (Robinson \& } \\
\text { Davidson, 1996:258) }\end{array}$ & $\begin{array}{l}\text { Direct observation and treatment of } \\
\text { the patient }\end{array}$ & $\begin{array}{l}\text { Written plan for clinical interactio } \\
19,70,71,89,105)\end{array}$ \\
\hline $\begin{array}{l}\text { 5. [Clinical course is defined as] "... taught or learnt at the hospital } \\
\text { bedside" (Fowler \& Fowler, 1995:246) }\end{array}$ & $\begin{array}{l}\text { "... taught or learnt at the hospital } \\
\text { bedside" }\end{array}$ & $\begin{array}{l}\text { Planned programme of clini } \\
\text { experiential learning }(6,7,10,1 \\
32,37,42,43,45,46,47,50,5 \\
67,75,76,78,79,84,91,98,99\end{array}$ \\
\hline $\begin{array}{l}\text { 6. [Clinical is defined as] "...at or for the treatment of patients" (Fowler \& } \\
\text { Fowler) }\end{array}$ & $\begin{array}{l}\text { The observation and treatment of } \\
\text { patients }\end{array}$ & \\
\hline $\begin{array}{l}\text { 7. [Clinical in nursing refer to] "...program that address those clinical } \\
\text { decisions that relate to the overt needs of clients' daily living activities..." } \\
\text { (Reilly \& Oerman, 1985) }\end{array}$ & $\begin{array}{l}\text { Clinical decisions that relate to the } \\
\text { overt needs of clients }\end{array}$ & \\
\hline $\begin{array}{l}\text { 8. Clinical "... of or pertaining to a sickbed, formed in English from Latin } \\
\text { "clinicus" (from Greek "klinikos" which means "of a bed"). Before } 1626 \text { the } \\
\text { word was defined as "... a bedridden person", borrowed from the Latin } \\
\text { word "clinicus" which as an adjective, means "... of or having to do with } \\
\text { bed" (Barnhart Dictionary of Etymology, 1988) }\end{array}$ & "of a bed" or "having to do with bed" & \\
\hline
\end{tabular}


Table 3: Surrogate terms and analysis of the concept course

\begin{tabular}{|c|c|c|}
\hline COLUMN 1 & COLUMN 2 & COLUMN 3 \\
\hline $\begin{array}{l}\text { 1. [Courses] "..should aim at developing student's critical thinking and } \\
\text { analysis, skills, competence in psychomotor, communication, and time } \\
\text { management skills, and to increase self-confidence in their ability to } \\
\text { perform as nurses" (Grealish \& Carroll, 1998) }\end{array}$ & $\begin{array}{l}\text { Developing learners' critical thinking } \\
\text { and analysis, skills, competence in } \\
\text { psychomotoric, communication, and } \\
\text { time management skills }\end{array}$ & $\begin{array}{l}\text { Planned programme of multi-modal edı } \\
\text { training }(2,88,93,96,103,107,117,118)\end{array}$ \\
\hline $\begin{array}{l}\text { 2. [Course] refers to a "... program of education and training leading to a } \\
\text { clinical nursing qualification" (SANC, 1993) }\end{array}$ & Programme of education and training & $\begin{array}{l}\text { Planned programme of intended clinic } \\
\text { outcomes }(18,20,22,23,24,25,28,29 \text {, } \\
63,104)\end{array}$ \\
\hline $\begin{array}{l}\text { 3. [Course] refers to "... all of the experiences children have under the } \\
\text { guidance of a teacher" (Hollis, Caswell \& Campbell, 1935) }\end{array}$ & $\begin{array}{l}\text { All of the experiences guidance of an } \\
\text { educator }\end{array}$ & $\begin{array}{l}\text { Intentional and deliberative study program } \\
24,25,28,29,33,34,49,54,57,58,9 \text { : } \\
110,112,115)\end{array}$ \\
\hline $\begin{array}{l}\text { 4. [Course] refers to "...all of the [clinical] learning of students which is } \\
\text { planned by and directed by the school to attain its educational goals" } \\
\text { (Tyler, 1949) }\end{array}$ & $\begin{array}{l}\text { Planned learning; directed by the } \\
\text { school to attain its educational goals }\end{array}$ & $\begin{array}{l}\text { Planned programme of clinical supervisior } \\
111,113,114,116,120)\end{array}$ \\
\hline $\begin{array}{l}\text { 5. [Course] refers to (".... the planned and guided [clinical] learning } \\
\text { experiences and intended learning outcomes, formulated through the } \\
\text { systematic reconstruction of knowledge and experiences under the } \\
\text { auspices of the school, for the learner's continuous and will-full growth in } \\
\text { personal-social competence" (Tanner \& Tanner, 1975) }\end{array}$ & $\begin{array}{l}\text { Planned and guided [clinical] learning } \\
\text { experiences and intended learning } \\
\text { outcomes } \\
\text { Systematic reconstruction of } \\
\text { knowledge and experiences }\end{array}$ & $\begin{array}{l}\text { Planned study programme that is dires } \\
\text { facilitation and application of clinical cc } \\
\text { (knowledge, skills, attitudes and values) ( } \\
6,39,44,53,69,74,87,90,92,100,101 \text {, }\end{array}$ \\
\hline $\begin{array}{l}\text { 6. [Course] "... involves experiential learning... that has a quality of } \\
\text { personal involvement - the whole person in both his feelings and cognitive } \\
\text { aspects being in the learning event" (Van Hoozer et al. 1987) }\end{array}$ & $\begin{array}{l}\text { Experiential learning } \\
\text { Personal involvement - the whole } \\
\text { person }\end{array}$ & \\
\hline $\begin{array}{l}\text { 7. [Courses] "... in nursing curriculum provide the means through which } \\
\text { the conceptual framework, philosophy, and objectives become } \\
\text { operationalized ..." (Reilly \& Oerman, 1985) }\end{array}$ & $\begin{array}{l}\text { Means through which the } \\
\text { [curriculum's] conceptual framework, } \\
\text { philosophy, and objectives become } \\
\text { operationalised }\end{array}$ & \\
\hline
\end{tabular}


Member departments were requested to analyse and discuss the definition and to give further input on the attributes of the concept as it is currently used during professional and educational discussions and interaction. The intention hereof was to identify the attributes of the concept clinical course as it is used during socialisation and repeated interaction (Rodgers, 1989:332), thereby enabling the researchers to develop a time-oriented grasp of the meaning of the concept clinical course. Only two of the 18 member nursing departments responded to the researchers' request for input. Based on the further input, a definition of the concept clinical course was formulated. Evidence of the multiple views of the members of FUNDISA is reflected in bold in Table 4.

Given the extent of the feedback from the eighteen nursing departments at the eighteen Universities reflected in the Newsletter of FUNDISA (FUNDISA, 1999) further input on the definition of the concept clinical course was requested at the FUNDISA annual general meeting (FUNDISA, 2002). The purpose for the request for input from the universities was to identify and clarify the meaning of the concept clinical course by means of the triangulation of data sources. During this meeting an almost half-an-hour long presentation on the process by which the concept was analysed and the results thereof were presented at this meeting. After the presentation time for input on the definition of the concept clinical course and the process of concept analysis was granted by the chairperson of the meeting. Of all the members present one individual requested that the concept must be defined in such a way that it also includes undergraduate programmes. Based on the recommended changes, the final definition of a "clinical course" was accepted by the peer group from which the initial uncertainty about this concept originated.

\section{Data analysis}

Forty-nine definitions related to the concept clinical course were identified from the literature. Excerpts of the definitions on both concepts are listed in column 1 of Table 2 and Table 3 respectively. From these definitions 120 characteristics of the concepts clinical and course were identified. This list of characteristics was evaluated by four independent experts, who are all nurse educators. After consensus about the characteristics of the concept, these characteristics were reduced to nine categories of characteristics, employing both deductive and inductive thinking skills of analysis, synthesis and inferences. This thinking-process is reflected in column 3 of Table 2 and Table 3 respectively. Employing the thinking skills of organising and systematising, the nine characteristics of the concept clinical course were clustered into three categories of characteristics.

Table 4: Evidence of the members of FUNDISA'S views

[A clinical course is defined as a planned, contextual, needs-driven, interactive educational and training programme] "...which is based on sound theoretical knowledge... that confers the holder of such clinical qualification the right to "register..." (input 1)

A clinical course is defined as an educational and training programme "...which is based on experiential learning in nursing practice settings..." (input 2)

A clinical course can be given via a "multimodal education and training process" (input 3 )

A clinical course as a programme of "authentic learning aimed not only at the application of clinical nursing competencies, but the application of those competencies in real life practice settings..." (input 4) 


\section{METHODS OF TRUSTWORTHINESS}

In this study, trustworthiness was ensured by means of the strategies for trustworthiness as devised by Guba and Lincoln (1985), viz. triangulation, peer group discussions and co-coding. Furthermore, Copi and Cohen's (1994:192-196) measures for good theoretical definitions were followed during the formulation of a definition for the concept clinical course.

Triangulation of data-sources was carried out. Peer group discussions were held with nurse educators about the characteristics of the concept clinical course. Furthermore, after the initial identification of the categories of characteristics of the concept, a preliminary definition based on these categories was formulated. This definition, together with the categories on which it was formulated, were sent via e-mail to fourteen of the 18 member departments of FUNDISA. Based on their input, a definition of the concept clinical course was formulated. To ensure that the characteristics are those of the concept clinical course and that the definition was valid and complete, a second consultation session during the 2002 annual general meeting of FUNDISA was sought. The final definition of the concept clinical course was formulated from this session. Adequate reference was made to the literature where the characteristics of the concept clinical course were identified and a dense description of the final categories of characteristics of the concept was done.

\section{CHARACTERISTICS OF THE CONCEPT CLINICAL COURSE}

From the analysis of the concept clinical course, three categories of characteristics were identified and are reflected in Table 5.
The first group of characteristics of the concept clinical course that will be described is the clinical course as an interactive programme of education and training involving clinical supervision.

\section{Interactive programme of multi-modal edu- cation and training that involves clinical supervision}

Education and training are frequently used together, but are often understood to mean different things. Education is seen as the development and understanding of the individual, whereas training is often seen as the development of specific skills and techniques required for a particular task or job (Grundy, 2001:261). The distinction between a programme of education and one of teaching is problematic because nurses in post-graduate clinical courses in nursing are, for instance, certainly engaged in education, but they should also be trained for the role of clinical practitioner.

In looking more closely at the aforementioned distinction of a clinical course as a programme of education or of training, the distinction seems to lie within the intention. A clinical course as a programme of education can be referred to as learning undertaken for the sake of curiosity or personal development. On the contrary, a clinical course as a training programme can be referred to as learning undertaken for the intention of developing competence for a social role, such as that of an advanced clinical nurse practitioner. Yet, a virtue of this distinction is that whether a clinical course is regarded as a programme of education or of training, both are not mutually exclusive. They should in fact co-exist and overlap (Callery, 2000:374).

Clinical nursing practice requires integration of think-

\section{Table 5: Characteristics of the concept clinical course}

- Interactive programme of multi-modal education and training that involves clinical supervision.

- Intentional, deliberative and needs-driven programme of authentic experiential learning that is contextual in nature.

- $\quad$ Planned programme of intended clinical learning outcomes aimed at the development and application of clinical competencies (knowledge, skills and values). 
ing, feeling and doing, focusing on performance and judgement in handling many variables and many levels of problem-solving. Clinical nurse practitioners are expected to have higher-order intellectual and communication skills, competent technical skills, and the ability to make decisions in the demanding and complex context of practice situations (Edmond, 2001:251; Grealish, 2000:231). It seems that the intention of a clinical course as a programme of education would be to equip and prepare clinical nurses with the knowledge and thinking skills necessary for making judgements, solving problems and to communicate this to others in an effective and efficient manner. As a programme of training, the intention of a clinical course would therefore be the development of specific skills and techniques required to perform a particular task or job, such as that of a clinical nurse practitioner. However, to achieve these ideals in clinical nursing education, and in nursing as a highly complex and challenging profession that exists within a rapidly changing health care environment, it is imperative that a clinical course would strike a fine balance between a programme of education and training in order to deliver nurses that are proficient in the current knowledge, thinking, procedural skills, attitudes and values necessary for providing safe and effective nursing care (Bowles, 2000:373). It can therefore be concluded that a clinical course in nursing is incomplete if it does not express both the intentions of education and training.

Furthermore, the word education according to Mellish, Brink and Paton (1998:6) is deduced from the Latin "e" (= from) and "ducere" (= to lead), which can be considered to mean leading someone from the known to the unknown or visa versa. This implies giving guidance, providing opportunities and facilities for learning and giving assistance to those that learn. Therefore, nursing education is described as a process whereby students are guided, assisted and provided with the means that enable them to learn the science and art of nursing so that this can be applied to the nursing care of people who are in need of such care (Mellish et al. 1998:7). This definition indicates an interactive relationship between someone who guides and assists (the educator) and the one who ought to be guided and assisted (the learner), using particular means (an educational programme or curriculum) to fulfil this function. Clark (1978:46) states: "a curriculum is an educational program designed to meet specific goals", within a relationship of support or guidance (Mellish et al. 1998:83). Therefore, it can be concluded that a clinical course is an interactive programme of education between the educator and the learner with the purpose of achieving the learning of particular principles and concepts.

However, in terms of the above definition, nursing education is described as an art and a science directed at providing human health care based on scientific principles and particular kinds of knowledge to apply personalised treatment and care of a highly skilled nature. This therefore implies that, besides the teaching of certain knowledge and principles through a process of education, nursing education is also a process of interactive training.

Training is essentially a task-orientated process. To provide competent personalised nursing care, a clinical course should also involve a component of training, thus enabling the nurse to master and demonstrate specific skills, attitudes and values to provide such care. The mastering of such skills, attitudes and values should be achieved under clinical supervision. Therefore, to overcome the hurdles or the gap and to strike a balance between a clinical course as both a programme of education (theory) and of training (practice), clinical supervision is essential.

Clinical supervision, according to Lyth (2000:728), is a support mechanism for practising professionals within which they can share clinical, organisational, developmental and emotional experiences with other professionals in a secure, confidential environment in order to enhance knowledge and skills. This process leads to an increased awareness of other concepts including accountability and reflective practice. Butterworth and Woods (undated:i-ii) are of the opinion that clinical supervision is "a formal process of professional support and learning which enables individual practitioners to develop knowledge and competence, assume responsibility for their own practice and to enhance consumer protection and safety of care in complex clinical situations."

A clinical course as an interactive programme of clinical supervision supports practice, enabling practitioners to maintain and promote standards of care and increases the self-assurance of nurses, particularly in 
the areas of problem-solving and clinical decision-making. It also increases their ability to support the patient and to take responsibility, increases job satisfaction, develops competence and moral sensitivity and reduces stress and burnout (Berggren \& Severinsson, 2000:67). Cutcliffe and Epling (1997:174-180) argue that clinical supervision can raise awareness in practitioners and helps them understand how supervision contributes to patient care, those being supervised and the organisation. From the aforementioned arguments it can be concluded that clinical supervision brings the learner, skilled clinical supervisor and patient together to reflect on the clinical practice situation. The aim is to identify solutions to problems, to improve practice, to increase understanding of professional issues and to support.

Thus, a clinical course that implements clinical supervision effectively should address three main areas, viz. the skills, resources and the commitment required from the participants (Lyth, 2000:726). Clinical supervision involves three people: the supervisor, the person being supervised and the patient, and that all issues covered in clinical supervision sessions should relate directly to patient care (Yegdich, 1998:193). In its position statement on clinical supervision, the United Kingdom Central Council for Nursing, Midwifery and Health Visiting (UKCC, 2002:1-2) is of the opinion that links between clinical supervision and management are important, but emphasises that clinical supervision is not a managerial control system. Therefore, the development and establishment of clinical supervision should involve managers, practitioners, skilled clinical supervisors and patients with the emphasis on a "light touch" management influence. Stakeholders should develop the process of clinical supervision according to local circumstances. Ground rules should be agreed upon so that the stakeholders approach clinical supervision openly and confidently and are aware of what is involved (UKCC, 2002: http://www.clinical-supervision.com/clinsup.htm).

It is clear from the aforementioned arguments that a clinical course is an interactive programme of education and training that involves clinical supervision with the intention of developing knowledge, skills, attitudes and values. Therefore, the second group of characteristics of a clinical course as an intentional needs-driven contextual programme of experiential learning will be described.

\section{Intentional, deliberative, needs-driven and contextual programme of authentic expe- riential learning}

Society expects nurses to be autonomous in their thinking and achievements in order to solve their personal and professional problems effectively and rapidly, to adapt swiftly and creatively to changes in their environments, and to work hard at self-actualisation. In general, society also requires that professionals prove their autonomy and accountability, transfer their knowledge rapidly from one domain to another and be committed and efficient in very complex situations (Fagin \& Lynaugh, 1992:213-220). To achieve these outcomes, learning should therefore be intentional and needs-driven, recognising the importance of experience in learning. Hunsberger, Baumann, Lappan, Carter, Bowman and Goddard (2000:278) are also of the opinion that it is crucial that a clinical course in nursing engages learners in a full, dynamic experience that captures the reality of clinical nursing.

According to Dumas, Villeneuve and Chevrier (2000:252), the ability to recognise the value of their experience as a starting point of professional development and continuing learning, allows nurses to remain above the waves of human and technological changes in their day-to-day professional world "only if they know how to learn from it". Therefore, the type of learning endorses and will influence the achievements of the aforementioned ideals.

Rogers describes experiential learning as personal involvement which is self-initiated and evaluated and has a pervasive effect on the learner. To Rodgers (1969:1), experiential learning is equivalent to personal change and growth. Rodgers feels that all human beings have a mutual propensity to learn and the role of the educator is to facilitate such learning. This includes setting a positive climate for learning, clarifying the purposes of the learner, organising and making available learning resources, balancing intellectual and emotional components of learning, and sharing feelings and thoughts with learners, without dominating the process.

According to Rodgers, learning is facilitated when the 
learner participates completely in the learning process and has control over its nature and direction. Learning is primarily based upon direct confrontation with practical, social, personal or research problems, while selfevaluation is the principle method of assessing progress or success. Rodgers (1969) also emphasises the importance of learning to learn and an openness to change. Rodgers and Frieberg (1994:10) discuss the application of the experiential learning framework to the classroom. Principles underlying the framework include that significant learning takes place when the subject matter is relevant to the personal interests of the learner. Learning which is threatening to the self (for example, new attitudes or perspectives) is more easily assimilated when external threats are minimised, while selfinitiated learning is the most lasting and pervasive.

According to Dumas (1995, in Dumas, Villeneuve \& Chevrier, 2000:252), teaching via the experience process and supporting learners in such a process, strives to:

- help adult learners to link theory to practice by developing their ability to transfer knowledge acquired from the classroom to the clinical setting, and from one clinical setting to another;

- think critically by developing their ability to make well-reasoned decisions in solving complex problems after thoughtful judgements involving many possible alternatives, and

- intervene creatively and professionally after sound reflection and detachment from actual and previous experiences by developing their abilities to intervene as planned with the client after thorough analysis of the data collected.

These interventions refer to different approaches of the learning process itself. To teach such an experiential approach of learning, universities and clinical educators must focus on helping adult learners acquire meta-cognitive skills. This means developing their abilities to monitor and evaluate their own learning patterns and activities, and to respond to self-correcting and self-regulating goals (Dumas, 1995:223). It also constitutes the basis of the teaching of the process of learning how to learn. This, according to Dumas, Villeneuve and Chevrier (2000:252), starts from the adult learner's own experience and this type of teaching tends to move away from teaching facts to teaching processes.
Dumas et al. (2000:253) believe that persons who know how to learn from their experiences are persons who function appropriately in any setting. To function appropriately in any setting means that one knows how to bring into operation attitudes and conducts that are appropriate for a particular experiential learning situation. Good functioning or know-how in experiential learning is believed to consist of integrated cognitive, affective and operational elements that can be developed during life in order to make learning more relevant for future experiences. Based on Kolb's experiential learning model (Kolb, 1984), Chevrier and Charbonneau developed their experiential learning competency model (Dumas et al. 2000:253). This model consists of five integrated components, four of which have been detailed from the works of Kolb (1984). According to Kolb (1984), learning is the process whereby knowledge is constructed through the transformation of experience that occurs in a four-phase cycle, namely concrete experience, reflective observation, abstract conceptualisation and active experimentation. Although he described these four phases in his model, he never detailed the elements in each of them. In fact, he was more interested in categorising learning styles than determining where a learner experienced difficulties. However, such information could enable the learner to learn more efficiently (Dumas, et al. 2000:253).

It is crucial that clinical courses in nursing engage learners in full dynamic experiences that capture the reality of clinical nursing (Hunsberger et al. 2000:278). Rapid technological advances within the health care system are making unparalleled clinical demands on a faculty at a time when university demands for faculty research portfolios are equally brisk. In a study on the extent of the relationships between nursing education and experience with clinical competence, Cruickshank, Mackay, Matsuno and Williams (1994:228) found that clinical experience and education exerted significant effects on the demonstration of clinical competence in nursing practice. The fact that clinical experience and educational preparation demonstrably influence competence level has certain ramifications. There is a need to maintain high-quality educational programmes as well as to continue to assist new graduates in adjusting to the work environment. As clinical experience is a characteristic of clinical nursing competence, it affirms the need to retain experienced 
nurses in patient care roles to ensure quality care. Based on the aforementioned arguments, it can be concluded that a clinical course should therefore be a programme of authentic experiential learning that is intentional, deliberative, needs-driven and contextual in nature. It is intentional, as it will be directed at learners' ability to learn from their experiences and, in order for such learning to be meaningful, is based on their needs and contexts.

The last group of characteristics deals with a clinical course as a planned programme of intended clinical learning outcomes aimed at the development and application of clinical competencies (knowledge, skills and values).

\section{Planned programme of intended clinical learning outcomes aimed at the development and application of clinical competencies (knowledge, skills and values)}

A clinical course is a planned programme of intended learning outcomes which, according to Posner and Rudnitsky (in Ornstein \& Hunkins, 1993:216), can be defined as "... statements of precisely what the student is to learn". This implies that an intended learning outcome is a declaration about the specifics to be learned for example, facts, concepts, principles, process, techniques and generalisation. Posner and Rudnitsky (op cit.) stress that the words intended learning outcomes require reflection. Intended means that the statements do not refer to accidental learning. Intended learning is the result of reflecting on information judged to be of worth. Also, the word intended means that the educational process is under a type of control for particular purposes. The term learning implies that the bottom line for planning is learner performance. An outcome can therefore imply a statement to identify the particular intent of a particular action. A meaningful outcome is one that communicates effectively to the reader the instructional intent or behaviour of a specific learning outcome (Ornstein \& Hunkins, 1993:217). Clinical learning should therefore be aimed at the development of clinical competencies.

Registered nurses hold a position of trust within society and have a responsibility to be competent. Public expectation is that nurses are competent not only at the point of registration, but throughout their careers. The term competence is used frequently, often inconsistently, and has many definitions. Prime Research and Development Limited (1998, in Grundy, 2001:261) identify two models of competence, viz. personal competence and occupational competence. Personal competence models focus on individuals' personal qualities, skills, knowledge, motives and aspirations - those characteristics an individual can bring to a job. Occupational models of competence focus on the outcomes that anyone who undertakes a work role is expected to achieve (Grundy, 2001:261).

According to Winter (1995), academics have treated competence-based approaches to professional curricula with suspicion. There has been widespread criticism that the competence-based approach is behaviourist, atomistic and reductionist (Elliot, 1991:298; Halsall, 1995:260-262). However, much of the public criticism outside academic circles has so far been confined to National Vocational Qualifications at lower levels (Ecclestone, 1997:66). A National Vocational Qualification (NVQ) in the context of Nursing Education in South Africa is the equivalent of a two year Enrolled Nursing Curriculum. As Boys (1995:6-7) points out, there is more to the NVQ model than behaviourist outcomes, although they may remain central to it. NVQ's emphasis on direct workplace relevance to a particular occupational role builds upon long-running criticism of higher education's approaches to professional learning, where too much abstract theory, academic self-interest and indulgence in what will be taught and not enough attention to work-place competence, are commonly heard criticisms (Ecclestone, 1997:65-70).

However, there appears to be no generally accepted definition of competence or agreement on the exact phenomena that indicate competence (O'Connor, Pearce, Smith, Vogeli \& Walton, 1999:334-341). Eraut (1995:204-205) describes competence as having a generic or holistic meaning which refers to a person's overall capacity, and the term competence refers to specific capabilities, which implies that competence can be divided into competencies. Ellis (1988:273) states that competence refers to a total of observable behaviours that occur in professional practice, and also to the non-observable attributes, capacities, disposi- 
tions, attitudes and values that the professional should have. These must however surface and be detectable in behaviours. Competence requires the application of theory and skill in the clinical situation. The practitioner must possess the necessary knowledge as well as mastery in psychomotoric, cognitive and affective skills to be effective. According to the United Kingdom Central Council for Nursing, Midwifery and Health Visiting (UKCC, 1999(a):35), competence is described as "the skills and ability to practice safely and effectively without the need for direct supervision".

A clinical course is a planned programme of intended learning outcomes focusing on the development of competencies, for example knowledge, skills, attitudes and values in the clinical nurse practitioner. A clinical course in nursing should therefore adopt both the positive features of vocational training and combine them with the positive features of traditional approaches (Ecclestone, 1997:70-72). Storey (1995:3435 ) has, for instance, demonstrated how a college of nursing made a formal link between the NVQ scheme and higher education by preparing its Project 2000 students to be able to achieve a diploma in higher education and a respected NVQ in management at level 3.

A clinical course in nursing education should therefore put forward nurse practitioners that are fit for practice based on health care needs. This will require increasing flexibility, which is not only meant to address recruitment problems but also recognises that learners enter at different levels, from different backgrounds and with different levels of knowledge and experience. Furthermore, it requires a re-focus of pre-registration education on outcomes-based competency principles to ensure the development of higher order intellectual skills and abilities and practices knowledge and skills essential to the art and science of nursing. Finally, closer working partnerships between higher education institutions and service providers are essential to support teaching and learning in the context of practice (UKCC, 1999b).

Based on the aforementioned characteristics of a clinical course, a conceptual definition thereof will be formulated.

\section{DEFINITION OF A CLINICAL COURSE}

Based on the concept analysis of the concept clinical course, certain characteristics were identified and the definition of the concept is formulated as follows:

A clinical course in nursing refers to a planned, deliberative, contextual, needs-driven, interactive multimodal education and training programme that is based on sound theoretical knowledge under the supervision of a clinical educator/facilitator that leads to a clinical nursing qualification. A clinical course as a programme of supervision brings the learner, skilled clinical supervisor and the patient together to reflect on the clinical practice situation. The aim of a clinical course is to develop clinical competencies particularly in the area of clinical problem solving and clinical decision-making, to promote standards of care and to achieve set clinical outcomes by means of authentic experiential learning, and that confers on the holder of such clinical qualification the right to register such qualification as an basic/additional qualification in terms of section 22 of the Nursing Act.

\section{CONCLUSION}

Clarifying the concept clinical course within nursing education is not easy, because of the multiple views that nurse educators have about education in nursing. According to Rodgers (1989:334), nursing has an interest in clarifying and developing its knowledge base and its conceptual foundation. The method of concept analysis offers a substantial contribution to continuing productive activity in this regard. Through further application and continuing evaluation of concept analysis, nursing education may be able to develop a strong conceptual foundation to enhance efforts towards the continuing development of knowledge in nursing and the achievement of its goals throughout its domain of intellectual concern.

The concept clinical course is very important for nursing education because of the potential benefits it can bring to the restructuring of nursing education in South Africa, and to the nursing profession in general. That includes clinical practice, research and management. It is vital that nurses understand what is meant by clinical course and what it is they are being urged to take on. Nurse educators should also be aware that 
there may be different but equally valuable perspectives on clinical courses and not allow this to become yet another barrier to what should be regarded as a clinical course, thereby hampering the accessibility of clinical nursing education to the people of the country. With this paper the authors provide an overview of the concept clinical course by promoting an understanding thereof, which enables nurse educators to fulfil its full potential, as nurse training now attempts to provide nurses with the skills to practice effectively and to deliver quality nursing care. Therefore, nurse educators and policy-makers are urged to utilise the definition of the clinical course wholeheartedly and to consider it during the development and offering of clinical courses in nursing education.

\section{ACKNOWLEDGEMENT}

The analysis of the concept clinical course was done while Dr Arries served on the FUNDISA Executive Committee. The authors would like to thank all the nursing science departments of the relevant universities and FUNDISA members for their time and creative interest in this research.

\section{REFERENCES}

BARNHART, RK (Ed). 1988: The Barnhart Dictionary of Etymology. Boston: HW Wilson.

BERGGREN, I \& SEVERINSSON, E 2000: The influence of clinical supervision on nurses' moral decision-making. Academic Search Premier Data Base. Sweden: Vanersborg.

BOYS, C 1995: National Vocational Qualifications; the outcomesplus model of assessment (In: Edwards A \& Knight P (Eds) 1995: Assessing competence in higher education. London: Kogan Page). BOWLES, K 2000: The relationship of critical-thinking skills and the clinical judgement skills of Baccalaureate nursing students. Journal of Nursing Education, 39(8):373-376.

BURNS, N \& GROVE, SK 1993: The practice of nursing research: Conduct, critique and utilization; second edition. Philadelphia: WB Saunders.

BUTTERWORTH, T \& WOODS, D (Undated): Clinical governance and clinical supervision: Working together to ensure safe and accountable practice. University of Manchester: School of Nursing, Midwifery and Health Visiting.

CALLERY, P 2000: Training and education: An analysis of quality assurance in teaching and nursing education. Nurse Education Today, 20:373-380.

CASWELL, HL \& CAMPBELL, DS 1935: Curriculum development.
New York: American Books.

CHALMERS, H; SWALLOW, VM \& MILLER, J 2001: Accredited work-based learning: An approach for collaboration between higher education and practice. Nurse Education Today, 21:597606.

CHAN, D 2002: Development of the clinical learning environment inventory: Using the theoretical framework of learning environment studies to assess nursing student's perceptions of the hospital as a learning environment. Journal of Nursing Education, 41(2):69-75.

CLARK, C 1978: Classroom skills for nurse educators. New York: Springer.

COLEMAN, JS 1976: Differences between experiential learning and classroom learning (In: Keeton, MT (Ed) 1976: Experiential learning: Rationale, characteristics and assessment. San Francisco, Jossey-Bass).

COPI, IM \& COHEN, C 1994: Introduction to logic; ninth edition. New York: MacMillan.

CRUICKSHANK, JF; MACKAY, RC; MATSUNO, K \& WILLIAMS, AM 1994: Appraisal of the clinical competence of registered nurses in relation to their designated levels in the Western Australian nursing career structure. International Journal of Nursing Studies, 31(3):217-230.

CUTCLIFFE, JR \& EPLING, M 1997: An exploration of the use of John Heron's confronting interventions in clinical supervision: Case studies from practice. Psychiatric Care, 4:174-180.

DUMAS, L; VILLENEUVE, J \& CHEVRIER, J 2000: A tool to evaluate how to learn from experience in clinical settings. Journal of Nursing Education, 39(6):251-258.

ECCLESTONE, E 1997: Energising or enervating: Implications of national vocational qualifications in professional development. Journal of Vocational Education and Training, 49:65-79.

EDMOND, CB 2001: A new paradigm for practice education. Nurse Education Today, 21:251-259.

ELLIOT, J 1991: Competence based training and the education of professions - is a happy marriage possible? Action research for educational change. Buckingham: Open University Press.

ELLIS, R (Ed) 1988: Professional competence and quality assurance in the caring professions. London: Chapman \& Hall.

ERAUT, M 1995: Developing professional knowledge and competence. London: Falmer.

FAGIN, CM \& LYNAUGH, JE 1992: Reaping the rewards of radical change: A new agenda for nursing education. Nursing Outlook, 40(5):213-220.

FUNDISA 1999: FUNDISA Academic booklet and newsletter. Fundisa.

FUNDISA 2001: Annual general meeting held in Potchefstroom, South Africa.

FUNDISA 2002: Annual general meeting held in Potchefstroom, 
South Africa.

GREALISH, L 2000: The skills of coach are an essential element in clinical learning. Journal of Nursing Education, 39(5):231-233. GREALISH, L \& CARROL, G 1998: Beyond preceptorship and supervision: A third clinical teaching model emerges for Australian nursing education. Australian Journal of Advanced Nursing, 15(2):3-11.

GRUNDY, L 2001: Pathways to fitness for practice: National vocational qualifications as a foundation of competence in nurse education. Nurse Education Today, 21:260-265.

GUBA, EG \& LINCOLN, YS 1985: Naturalistic inquiry. New York: Sage.

HALSALL, R 1995: Assessing competence in teacher education. (In: GRUNDY, L 2001: Pathways to fitness for practice: National vocational qualifications as a foundation of competence in nurse education. Nurse Education Today, 21:260-265).

HOLLIS, L; CASWELL, \& CAMPBELL, 1935: Curriculum development. New York: American Books.

HUNSBERGER, M; BAUMANN, A; LAPPAN, J; CARTER, N; BOWMAN, A \& GODDARD, P 2000: The synergism of expertise in clinical teaching: An integrative model for nursing education. Journal of Nursing Education, 39(6):278-282.

KOLB, DA 1984: Experiential learning: Experience as the source of learning and development. Englewood Cliffs, NJ: Prentice Hall. LONGSTREET, WS \& SHANE, HG 1993: Curriculum for a new millennium. Boston: Allyn \& Bacon.

LYTH, GM 2000: Clinical supervision: A concept analysis. Journal of Advanced Nursing, 31(3):722-729.

MELLISH, JM; BRINK, HL \& PATON, F 1998: Teaching and learning: The practice of nursing; fourth edition. Johannesburg: Heinemann. O'CONNOR, SE; PEARCE, J; SMITH, RL; VOGELI, D \& WALTON, P 1999: Monitoring the quality of pre-registration education; development, validation and piloting of competency-based performance indicators for newly qualified nurse. Nurse Education Today, 19:334-341.

ORNSTEIN, AC \& HUNKINS, F 1993: Curriculum foundations, principles and theory; second edition. Boston: Allyn \& Bacon PORTER-O'GRADY, T 2001: Profound change: $21^{\text {st }}$ century nursing. Nursing Outlook, 49(4):182-186.

POSNER, GJ \& RUDNITSKY, AN 1990: Course design; second edition. New York: Longman.

PRIME RESEARCH AND DEVELOPMENT Ltd 1998: The assessment of competence (paper to inform developments of the specialist practice framework written for the UKCC) (In: GRUNDY, L (Ed) 2001: Pathways to fitness for practice: National vocational qualifications as a foundation of competence in nurse education. Nurse Education Today, 21:260-265).

QUINN, FM 1980: The principles and practice of nursing education; second edition. London: Croom Helm.
READ, S 1995: Catching the tide: New voyages in nursing? Sheffield Centre for Health and Related Research (SCHARR). Sheffield: University of Sheffield.

RICHARDSON, G \& MAYNARD, A 1995: Fewer doctors? More nurses? A review of the knowledge base of doctor-nurse substitution. Discussion Paper 135. Centre for Health Economics University of New York.

ROBINSON, M \& DAVIDSON, G 1996: Chambers $21^{\text {st }}$ Century Dictionary. Edinburgh: Chambers.

ROCHE, JP 2002: A pilot study of teaching clinical decision making with the clinical educator model. Journal of Nursing Education, 41(8):365-368.

RODGERS, BL 1989: Concept, analysis and the development of nursing knowledge: The evolutionary cycle. Journal of Advanced Nursing, 14:330-335.

RODGERS, C 1969: Freedom to learn. Columbus: Merrill.

RODGERS, CR \& FRIEBERG, HJ 1994: Freedom to learn; third edition. Columbus, $\mathrm{OH}$ : Merrill/Macmillan.

RUGG, H 1947: Foundations for American education. New York: World Book.

SOUTH AFRICAN NURSING COUNCIL, 1993: Regulations relating to the course in clinical nursing science leading to registration of an additional qualification (Regulation 212 of 19 February 1993). Pretoria: Government Printers.

SOUTH AFRICAN GOVERNMENT, 1997: National plan for Higher Education. Pretoria: Government Printers

STOREY, 1995: NVQ's as part of the pre-registration diploma. Nursing Times, 91:34-35.

TABA, H 1962: Curriculum development: Theory and practice. New York: Harcourt Brace Jovanovich.

TANNER, D \& TANNER, L 1975: Curriculum development. New York: Macmillan.

TANNER, CA 2002: Clinical education, Circa 2010. Journal of Nursing Education, 41(2):51-52.

TYLER, RW 1949: Basic principles of curriculum and instruction. Chicago: University of Chicago.

UKCC-See UNITED KINGDOM CENTRAL NURSING COUNCIL FOR NURSING, MIDWIFERY AND HEALTH VISITING

UNITED KINGDOM CENTRAL NURSING COUNCIL FOR NURSING, MIDWIFERY AND HEALTH VISITING 1999a: Fitness for practice. London: UKCC.

UNITED KINGDOM CENTRAL NURSING COUNCIL FOR NURSING, MIDWIFERY AND HEALTH VISITING 1999b: Entry to training requirements for pre-registration nursing and midwifery programs. London: UKCC Registrar's Letter 17/1999.

UNITED KINGDOM CENTRAL NURSING COUNCIL FOR NURSING, MIDWIFERY AND HEALTH VISITING 2002: Position statement on clinical supervision for nursing and health visiting. http:// www.clinical-supervision.com/clinsup.htm 
VAN DER HORST, H \& MCDONALD, R 1997: OBE: Outcomesbased Education: A teachers manual. Pretoria: Kagiso.

VAN HOOZER, HL; BRATTON, BD; OSTMOE, PM; WEINHOLTZ, D; CRAFT, MJ; GJERDE, CL \& ALBANESE, MA 1987: The teaching process: Theory and practice in nursing. Connecticut: AppletonCentury-Crofts.

WALKER, LO \& AVANT, KO 1995: Strategies for theory construction in nursing; third edition. California: Appleton \& Lange.

WILSON, J 1963: Thinking with concepts. New York: Cambridge University Press.

WINTER, R 1995: The assessment of professional competencies: The importance of general criteria (In: Edwards A \& Knight $P$ (Eds) 1995: Assessing competence in higher education. London: Kogan Page).

YEGDICH, T 1998: How not to do clinical supervision in nursing. Journal of Advanced Nursing, 28:193-202. 